biology deals with parts and events which are manifestations of the co-ordinated whole which we call the life of the organism. Hence, it looks as if, while we shall retain the old physical and mathematical conceptions for practical purposes, the more fundamental physical and mathematical conceptions are assuming characters similar to those of biology. This fundamental attitude was further explained by $\mathrm{Mr}$. L. L. Whyte, who showed how the study of the structure of material bodies and of radiation is beginning to influence biology. The adequate description of ordered structures, which was impossible by classical methods, is now expressed by 'quantum conditions' which refer to systems as a whole, each part having in it definite positions and motions. Thus the conflict between the analytical methods of classical physics and the organic concepts of biology is thinned down to such a point that it may be hoped to see the study of biology leading ultimately to the discovery of exact biological laws defining the struetural char. acteristics of living systems.

Dr. Needham's ery for an increase in the use of the style of physics in biology, and Dr. Russell's slogan, 'Back to Aristotle', alike strengthened the resistance of the mechanists, who, lilze Prof. L. Hogben (London), emphasise that there was never a time when biologists entertained more confidence in the usefulness of classical physico-chemical methods as instruments for arriving at predictable conclusions about how organisms behave. The ecclesiastical origins of modern culture and the contemporary social unrest were quoted as causes for the public distrust of the mechanist conception of life, at a time when the materialistic tradition appears to be entrenched in the laboratory more strongly than ever before. Dr. J. H. Woodger (London) went a step further by proposing to apply to the study of biological questions, not only physical methods, but also an appropriate notation of mathematical logic derived from the method of Russell and Whitehead. He was thus led to predict a gradual displacement of the notion of 'stuff' by that of 'svstem'; so that the notion of 'protoplasm' or 'living matter' would have to go the way of 'hereditary substance', when the scientific worker will learn to think of cells more in term of systems, and less in terms of stuff. A mechanist conception of biology seemed to linger also in the mind of Prof. A. Joffe (Moscow), though he admitted that physicists have to use biological methods for the finest measurements. He quoted the experiments of Prof. Gurtwitseh, who claims to have discovered 'biological rays ', in support of the closer relationship between physies and biology, which will lead in time, he hoped, to the disappearance of the 'mysterious' vitalistic conceptions.

The fourth section of the Congress, presided over by Sir Henry Lyons, Director of the Seience Museum, dealt with "The Interdependence of Pure and Applied Science". Sir Napier Shaw, Prof. C. H. Desch, Prof. F. G. Donnan, Dr. G. Windred, Mr. R. V. Vernon, Dr. Marie Stopes, and Prof. W. Mitkewich illustrated the various aspects of the problem, and seemed to agree that a study of scientific history makes it evident that there can be no independence between pure research and experiment on one hand, and the practical application of scientific principles on the other hand. Further, it appears that the present tendency of intense specialisation makes the progress of science more than ever dependent upon the coordination of pure and applied science.

At a meeting of the Committee on July 5, the following were elected members of the International Council for the period 193l-34: Prof. Karl Sudhoff, of Leipzig (President); Prof. Gino Loria (Genoa), Dr. Charles Singer (London), Prof, Paul Diepgen (Berlin), Prof. Julian Ribera (Madrid), Prof. George Sarton (Harvard); Mme. Hélène Metzger, of Paris (Treasurer), and M. Aldo Mieli, of Paris (Secretary). The next Congress will be held in Berlin in 1934.

Such was the general trend of the labours of the Second International Congress of the History of Science and Technology. As Dr. Singer has long been claiming, the history of science can take its place not only among the departments of high scholarship, but also as an integral part of training and discipline in the general study of history. Science cannot assume her just position in education until the educator himself recognises the part that seience has taken in shaping the social and intellectual environment in which we live. If the scientific process come to be recognised as a great part of our great inheritance, the Congress will have gone a good way towards achieving its objective. THOMAS Greenwood.

\title{
The British Australian New Zealand Antarctic Research Expedition.
}

THE second cruise of the Discovery, under the title of the British Australian New Zealand Antarctic Research Expedition, ended on March 27 with the arrival of the ship and party at Melbourne. The health of Sir Douglas Mawson and his men has been excellent, and they have added greatly to our scientific knowledge of the Antaretic continent.

It has been definitely established that the coast-line is continuous through a great arc from Cape Adare to Enderby Land, which is nowhere far removed from the Antarctic Circle. New land totalling $16^{\circ}$ of longitude has been discovered, and further detailed charting has been carried out of the $13^{\circ}$ discovered on the first cruise last year. The field work extended through onethird of the circuit of the Antarctic region, beginning at the new 180 th meridian and ranging west to long. $60^{\circ} \mathrm{E}$. Additional features have been added to the coast lines of Adelie Land and Wilkes Land. It has been shown that there is no land in the latitudes assigned for North's Highland, Totten's Highland, or Budd's Land. The name Banzare Land (from the initials of the Expedition's title) has been given to a stretch of territory running from a well-defined cape near the juncture of the 66 th parallel and the 127 th meridian. It is proposed to maintain the title Sabrina Land for an area observed from the aeroplane between the 115th and 116th meridians at about the 66th parallel. At the end of Wilkes Land is an ice land about $1300 \mathrm{ft}$. high, which has been charted as Bowman Iceland, in honour of the Director of the American Geological Society. Princess Elizabeth Land is a newly discovered region commencing at the 80 th meridian on the 76 th parallel and extending south and west in a great sweep to Cape Amery. All the salient features of the MacRobertson Land coast have been charted and named. It is a most interesting region, diversified with mountains, peaks, and islands.

Apart from the geographical work, an immense mass of scientific data has been accumulated by the Expedition. Considerable delineation of the sea floor has been possible with an echo sounder, and many examinations of vertical marine stations were carried out. Daily nettings for marine life and

No. 3219 , VoL. 128] 
chemical examination of waters have been made, as well as investigations on bacteria in sea water and their rôle as denitrifiers. A two-hourly meteorological record was maintained, and the pilot balloon work was very successful. An interesting fact established is that the violent winds of certain parts of the Antaretic are mainly confined to the surface, seldom extending more than $500 \mathrm{ft}$. or $1000 \mathrm{ft}$. above groundlevel. Useful observations in magneties, solar radiation, and cosmic penetration have been made, while, of course, a rich harvest has been reaped in glaciology, geology, and ornithology.

The Discovery sailed from Melbourne about the middle of April and, if not delayed, may be expected in London shortly.

\section{A New Heat Engine.}

$A^{\mathrm{T}}$ the Royal Society of Arts on June 4, Mr. J. F. J. Malone, in a paper entitled "A New Prime Mover ", gave a description of a form of heat engine, invented by himself, in which the working medium is a liquid instead of a gas. In the course of his paper he stated that though mercury and oil have been tried, water has been found to be the most suitable medium, and in the engines to which reference was made only water has been used.

The main parts of the new form of engine consist of one or more working cylinders, a large number of long thick steel tubes in each of which is a movable displacer or regenerator, and a furnace. The tubes the author calls the thermodynamic tubes or 'T.D. tubes', and the regenerators, the thermodynamic piles or 'T.D. piles'. The tubes are closed at one end and at the other end are connected by pipes to the working cylinders. They are set in groups with their closed ends in the furnace, while the other ends are surrounded by water for cooling. The T.D. piles are built up of thin plates or tubes very closely spaced. The interior of the T.D. tubes, the very narrow spaces in the piles, the connecting pipes, and the working cylinders form a closed system completely full of water, which, when the engine is prepared ready for starting, is under an initial pressure of 1.4 tons per sq. in.

The engine depends for its action on the alternate expansion and contraction of the water in the system, due to the heating and cooling of the water in the T.D. tubes and piles, as the latter are moved to and fro in the tubes. For all practical purposes, the moving of the piles, which is done automatically by the engine, is equivalent to the alternate application and removal of the source of heat. Under these conditions the moving of the piles causes the pressure to rise to about 5.3 tons in one part of the stroke and then to fall to 1.4 tons per sq. in. Much ingenuity has been shown in the construction of the piles, which at first sight might appear likely to give trouble, but which have proved reliable on service.

Unfortunately, though the paper gave a few details of the several engines which have been built and run, these were by no means sufficient to form an estimate of the place the engine is likely to fill. One experimental engine was said to have run over $30,000,000$ revolutions, and on three brake tests by three different independent engineers an indicated efficiency of 27 per cent was obtained. It was also stated that allowing for furnace and mechanical losses, it was anticipated with a 100 h.p. engine an over-all efficiency of 20 per cent can be obtained, and this on a weight of about $330 \mathrm{lb}$. per indicated horse power. In the conclusion of his paper Mr. Malone claimed that the new engine possesses features which make it suitable both for locomotives and for ships.

\section{University and Educational Intelligence.}

Birmingham.--The degree of D.Sc. has been awarded to the following: Jonquei Su-Kwang Lee, for published work on "The Fusulinidæ of North China " (Palceontologia Sinica, series B, vol. 4), "Some Characteristic Structural Types in Eastern Asia and their Bearing upon the Problem of Continental Movement", "Geology of the Gorge District of the Yang-tse with special Reference to the Development of the Gorge ", and other papers ; Harry W. Webb. for published work on "Absorption of Nitrous Gases ", "Limitation of the Capacity of Platinum Catalyst" in Ammonia Oxidation ", and other papers.

Dr. A. Stanley Barnes has been appointed Dean of the Faculty of Medicine, in succession to Prof. Brash.

The following appointments have been made: Dr. R. H. Hoplsins, lecturer and head of the Department of Brewing in the Heriot-Watt College, Edinburgh, to the Adrian Brown chair of brewing; Mr. R. D. Lockhart, lecturer in anatomy, University of Aberdeen, to the chair of anatomy; Mr. P. Gray and Mr. D. Richards, to be resident staff tutor's for adult education under the Joint Committee of the Tniversity and the W.E.A.

Prof. A. M. Carr-Saunders has accepted an invitation to hold the Muirhead Lectureship for a further year.

CAMrridge.-The Harkness scholarship for proficiency in geology, of value $£ 117$, has been awarded to Miss F. E. S. Caldwell, of Newnham College.

The Frank Smart prizes have been awarded to P. W. Richards, of Trinity College, for botany, and P. Ullyett, of 'Trinity College, for zoology.

EDINBURGH. - At the graduation ceremony on July 2 the honorary degree of doctor of laws was conferred on the following, among others: Dr. E. J. Allen, Director of the Marine Biological Laboratory, Plymouth ; Sir George Andreas Berry, M.P. for the Scottish Universities, formerly lecturer in ophthalmo logy in the University of Edinburgh; and Sir Walter Morley Fletcher, secretary of the Medical Research Council.

The degree of doctor of science was conferred on Lucy Boyd, for a thesis on "Studies in the PostSeminal Development of the Monocotyledonous Embryo "; A. Cunningham, for a thesis on "Studies on Soil Micro-Organisms"; Esmé Mary Gilroy, for a thesis on "The Influence of Arginine upon Growth and Tissue Repair" ; Dr. M. Young, for a thesis on "A Contribution to the Study of the Growth of the Face in Childhood".

LEEDS.-At a graduation ceremony in connexion with the hundredth anniversary of the Leeds School of Medicine, the following honorary degrees were conferred, among others: Degree of doctor of lawsProf. A. G. Barrs, emeritus professor of medicine at Leeds and for more than fifty years connected with the School of Medicine; Sir John Bland-Sutton, consulting surgeon at the Middlesex Hospital ; Lord Dawson of Penn, president of the Royal College of Physicians; and Sir George Newman, Chief Medical Officer, Ministry of Health. Degree of doctor of science-Sir Walter Morley Fletcher, secretary of the Medical Research Council ; and Sir Frederiek Gowland Hopkins, president of the Royal Society

London.--The late Mr. J. F. H. Knight has bequeathed to the University a moiety of his residuary estate for the furtherance of teaching and research in the University. The bequest is expected to amount to about $£ 25,000$. 